\title{
- UWARUNKOWANIA ZACHOWAŃ SAMOBÓJCZYCH DZIECI I MŁODZIEŻY
}

\section{DETERMINANTS OF SUICIDAL BEHAVIOURS IN CHILDREN AND ADOLESCENTS}

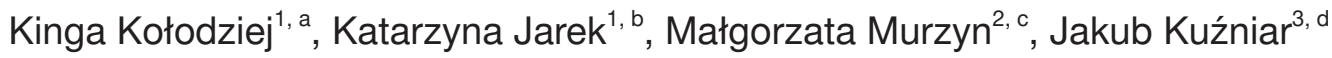 \\ ${ }^{1}$ Wydział Nauk o Zdrowiu, Uniwersytet Jagielloński, Collegium Medicum w Krakowie \\ ${ }^{2}$ Szpital Kliniczny im. dr. Józefa Babińskiego SP ZOZ w Krakowie \\ ${ }^{3}$ Wydział Lekarski, Śląski Uniwersytet Medyczny w Katowicach \\ ${ }^{a}$ https://orcid.org/0000-0001-6780-8686 \\ ${ }^{\mathrm{b}} \mathrm{https} / / /$ orcid.org/0000-0001-8027-4906 \\ ${ }^{\mathrm{c}}$ https://orcid.org/0000-0001-7978-4829 \\ ${ }^{\mathrm{d}}$ https://orcid.org/0000-0002-8793-3334
}

DOI: https://doi.org/10.20883/pielpol.2020.22

\begin{abstract}
STRESZCZENIE
Podejmowanie prób samobójczych u dzieci i młodzieży stanowi obecnie istotny problem w społeczeństwie. Zachowania suicydalne nie są uzależnione od jednego bezpośredniego powodu, lecz od wielu złożonych czynników na poziomie indywidualnym, rodzinnym, społecznym, a także sytuacji życiowej oraz własnych mechanizmów obronnych. Podczas gdy podejmowanie prób samobójczych u dzieci jest stosunkowo rzadkie, to statystyki wśród młodzieży, przez cały okres dojrzewania, mają tendencję wzrostową. W Polsce w 2018 roku grupa osób podejmujących zachowania suicydalne w wieku $7-18$ lat to $6,9 \%$, w tym $1,9 \%$ zakończonych zgonem. Trafna identyfikacja uwarunkowań samobójstw wśród osób w wieku rozwojowym to kluczowy czynnik decydujący o prowadzeniu ukierunkowanych i skutecznych działań profilaktycznych, a także ulepszeniu wczesnej diagnostyki i wdrożeniu odpowiednich działań terapeutycznych.
\end{abstract}

SŁOWA KLUCZOWE: samobójstwa dzieci, samobójstwa młodocianych, depresja.

\section{Wprowadzenie}

Prowadzone na przestrzeni ostatnich lat badania nad samobójstwami pozwoliły na sformułowanie wniosku, iż zachowania suicydalne obejmują szeroką gamę zachowań o charakterze autodestrukcyjnym, które są wynikiem interakcji pomiędzy czynnikami biologicznymi, psychologicznymi, socjologicznymi i środowiskowymi [1]. Pomimo tego, że śmierć dotyka jednostek, to ma ona także wymiar społeczny, a samobójstwa są wskaźnikiem integracji oraz dezintegracji społeczeństwa [2].

Celem pracy była analiza uwarunkowań towarzyszących podejmowaniu prób samobójczych wśród

\begin{abstract}
Suicide attempts in children and adolescents constitute an important problem in society today. Suicidal behaviour does not depend on one direct cause, but on many complex factors at individual, family, social, life situation and self-defence levels. While suicide attempts in children are relatively rare, statistics among young people tend to increase throughout adolescence. In 2018, the group of persons undertaking suicidal behaviors at the age of $7-18$ in Poland reached $6.9 \%$, including $1.9 \%$ resulting in death. Accurate identification of suicide determinants among people at developmental age is a key factor determining the conduct of targeted and effective preventive measures, as well as the improvement of early diagnosis and implementation of appropriate therapeutic measures.
\end{abstract}

KEYWORDS: child suicide, juvenile suicide, depression.

dzieci i młodzieży. Przedmiotem rozważań były podstawowe definicje oraz statystyki dotyczące samobójstw, a także najczęstsze motywy podejmowania zachowań suicydalnych przez wyżej wymienioną grupę wiekową. W artykule przedstawiono również najważniejsze zagadnienia dotyczące profilaktyki zjawiska.

\section{Zagadnienia dotyczące samobójstw}

Klasyczna definicja samobójstwa została przedstawiona przez Émile'a Durkheima i została określona jako „każdy przypadek śmierci będący wynikiem bezpośredniego lub pośredniego, negatywnego lub pozytywnego 
działania, wykonanego przez samą ofiarę, która wie, jaki będzie rezultat tego działania”. Definicja Durkheima cechuje się znaczną pojemnością znaczeniową, co sprawia, że jest obarczona wadami - nie uwzględnia przyczyn zamachów suicydalnych, a także zachowań autodestrukcyjnych, które nie muszą być związane z celowym zamiarem śmierci [3, 4].

Samobójstwa, czyli zamachy samobójcze, dzielą się na podstawowe grupy: samobójstwa dokonane, kończące się odebraniem sobie życia oraz niedokonane (usiłowane), niekończące się śmiercią, z uwagi na wystąpienie okoliczności umożliwiających odratowanie lub przeprowadzenie zamachu w sposób, który zapewnia odratowanie. Do samobójstw usiłowanych zaliczane są także tzw. próby samobójcze, których liczba jest większa od samobójstw dokonanych. Znacznie częściej podejmują je ludzie w młodszym wieku, w większości kobiety. Podkreśla się, że próby samobójcze są zazwyczaj przejawem wołania o pomoc innych osób [5, 6].

Zenomena Płużek wyróżniła trzy typy samobójstw, uzależniając je od intencji towarzyszących człowiekowi przy ich podejmowaniu. Pierwszym z wyodrębnionych typów jest „samobójstwo prawdziwe”, które jest przejawem agresji skierowanej na własną osobę bądź zorientowanej „na zewnątrz”. Osoba czuje się mało wartościowa, winna za swoje porażki, za cel ma odebranie sobie życia. Drugi typ to „samobójstwo rzekome”, gdzie sprawcy nie wyrażają jednoznacznie chęci odebrania sobie życia, lecz śmierć jest dla nich ucieczką od trudności, których nie mogą lub nie chcą pokonać. Rzadko towarzyszące są myśli na temat sensu życia, dominuje koncentracja na własnych trudnościach, które usilnie chce się pokonać. „Samobójstwo rzekome” często jest wynikiem depresji, poczucia winy bądź rezygnacji, wiąże się z obniżeniem mechanizmów obronnych. Z "samobójstwem demonstratywnym” mamy do czynienia, gdy sprawca prezentuje obojętną postawę wobec życia i śmierci, a zamach suicydalny ma służyć zwróceniu na siebie uwagi lub jest przejawem szantażu. Człowiek, poprzez tego typu akt samobójczy, wyraża także swoją wrogość do innych, których wini za własne porażki. „Samobójstwo demonstratywne” ma związek z bezradnością, brakiem umiejętności nawiązania kontaktu z osobami w bliskim otoczeniu [7, 8].

\section{Epidemiologia zachowań samobójczych wśród dzieci i młodzieży}

Zgodnie z raportem opublikowanym przez polską Policję w 2018 r. w całym kraju popełnionych zostało 11167 zamachów samobójczych, z czego 8364 dotyczyło mężczyzn, a 2803 kobiet. 5182 zamachy zakończyły się zgonem, z czego śmierć poniosło 4471 mężczyzn i 711 kobiet. Podczas gdy podejmowanie prób samobójczych u dzieci jest stosunkowo rzadkie, to statystyki wśród młodzieży, przez cały okres dojrzewania, mają tendencję wzrostową. W 2018 r. w grupie wiekowej od 0 do 6 lat nie została podjęta żadna próba samobójcza, natomiast w przedziale wiekowym 7 do 12 lat podjętych zostało ich 26 . W tym samym roku 746 osób w przedziale wiekowym 13 do 18 lat dokonało zamachu samobójczego. Zamachy zakończone zgonem najczęściej spowodowane były powieszeniem się, skokiem z wysokości oraz rzuceniem się pod pojazd w ruchu. Najczęstszym potwierdzonym powodem popełnienia samobójstwa była choroba lub zaburzenie psychiczne oraz nieporozumienia bądź przemoc w rodzinie [9].

\section{Uwarunkowania zachowań samobójczych wśród dzieci i młodzieży}

\section{Do społecznych czynników ryzyka zalicza się: \\ Czynniki związane z rodziną}

Erwin Ringel wyróżnił trzy grupy czynników, które podnoszą ryzyko zamachu samobójczego: konflikty pomiędzy rodzicami, zbyt mało przekazywanej miłości oraz miłość cechująca się zaborczością [10]. Zgodnie ze stanowiskiem Jerzego Dierżanowskiego najdotkliwszą sytuacją traumatyczną dla dziecka jest rozwód rodziców. Według autora atmosfera nieustannych kłótni prowadzi do utraty zaufania, zmniejszenia poczucia bezpieczeństwa oraz osłabienia więzi emocjonalnej między rodzicami i dzieckiem. Dziecko sytuacje tego typu odbiera w kategoriach subiektywnych, co powoduje, że czuje się niekochane, małowartościowe, odrzucone, w szczególności kiedy musi opowiedzieć się po jednej ze stron konfliktu [11]. Młodociani wychowywani przez jednego rodzica mogą być zarówno obarczeni nadmiernymi wymaganiami bądź doświadczać opieki rodzicielskiej w niewielkim stopniu. Rodzice mogą wykazywać dwie odmienne postawy wychowawcze: nadmiernie wymagającą lub nadmiernie opiekuńczą. Opiekunowie, którzy nie radzą sobie z wypełnieniem codziennych czynności, stawiają dzieciom wymagania, które przekraczają ich możliwości psychofizyczne. Rezultatem takiego działania jest obwinianie potomka za niespełnienie oczekiwań, co powoduje niechęć do rodzica czy brak wiary we własne siły. Rodzice, którzy mają tendencję do wykazywania postawy nadmiernie opiekuńczej, chcąc wynagrodzić dziecku sytuację rodzinną, cechują się uległością oraz akceptacją niewłaściwych zachowań. Taka postawa skutkuje ograniczeniem autonomii dziecka oraz jego kontaktów społecznych, prowadząc do niezaradności życiowej, co może być przyczyną odbierania przez potomka otoczenia jako zagrażającego [12]. Najczęściej występujące relacje w rodzinach, w których doszło do wystąpienia zamachów samo- 
bójczych, to: nadmiernie zaangażowana, kontrolująca, krytyczna matka, przy niezaangażowanym ojcu [13]. Wyniki badań Makary-Studzińskiej wskazują, że uczucie emocjonalnego odtrącenia przez rodziców ma największy wpływ na podejmowanie prób samobójczych przez młodzież. Równie istotne czynniki związane z rodziną, predysponujące do wykonania zamachu na swoje życie, to konflikty z rodzicami, śmierć jednego lub obojga z nich, a także choroba alkoholowa dotycząca zarówno matki, jak i ojca [14].

\section{Czynniki związane ze środowiskiem szkolnym}

Sytuacjami sprzyjającymi kształtowaniu się myśli samobójczych mogą być częste konflikty z nauczycielami, rówieśnikami, częste zmiany szkół, trudności w przyswajaniu wiedzy lub brak osiągnięć w nauce. Powodują one negatywne nastawienie do szkoły oraz jej środowiska. Wysokie wymagania nauczycieli, bez odpowiedniego wsparcia, bezosobowe relacje z nauczycielami, przemoc, brak zajęć rozwijających zainteresowania uczniów zwiększają ryzyko podjęcia próby [15]. Dominującym czynnikiem, ściśle związanym z porażkami szkolnymi uczniów, które mają wpływ na podejmowanie zamachu samobójczego, jest odrzucenie przez rówieśników [14].

\section{Do psychologicznych czynników ryzyka należą: Wydarzenia traumatyczne}

Ryzyko podjęcia zamachu samobójczego rośnie wraz z liczbą niekorzystnych doświadczeń w dzieciństwie. Zaliczają się do nich: przemoc wobec matki, rozwód bądź separacja rodziców, choroby psychiczne w rodzinie, pobyt w więzieniu członka rodziny, doświadczenie przemocy fizycznej, a także śmierć rodzica. U osób, które doświadczyły nadużycia emocjonalnego, fizycznego czy seksualnego, ryzyko popełnienia samobójstwa jest o 2-5 razy większe niż u innych [16]. Wśród rodzin, w których jeden z jej członków popełnił samobójstwo, obciążenie wystąpienia zamachu samobójczego jest większe [17].

Dzieci, które doświadczyły molestowania seksualnego, mają trudności w kontaktach z ludźmi, są wobec nich nieufne, czują lęk wobec partnerów seksualnych w późniejszym wieku [18]. Skutki molestowania manifestują się odmiennie w różnych grupach wiekowych. Wśród dzieci przedszkolnych (od 0 do 6. roku życia) najczęstsze to: niepokój, PSTD, nieodpowiednie zachowania seksualne. U dzieci szkolnych (od 7. do 12. roku życia) najczęściej stwierdzono: lęk, agresję, koszmary, problemy szkolne i zachowania regresywne. U nastolatków (od 13. do 18. roku życia) dominowały: depresja, wycofanie, samouszkodzenia, tendencje samobójcze [19].
Traumatyczne wydarzenia wpływają negatywnie na dalsze życie młodych osób, w szczególności gdy nie mogą one liczyć na wsparcie bliskich [13]. Szczególnie traumatyczne wydarzenie, powodujące uczucie zagrożenia, strach i bezradność, może prowadzić do wystąpienia zespołu stresu pourazowego (Posttraumatic Stress Disorder, PTSD), który manifestuje się lękiem, nawracającym przeżywaniem urazu, niepokojem, obniżonym nastrojem, odrętwieniem, a także agresją [16].

\section{Umiejętności życiowe}

Zgodnie ze stanowiskiem Światowej Organizacji Zdrowia umiejętności życiowe to zdolności do pozytywnego zachowania oraz przystosowania, które pozwalają jednostce radzić sobie z wyzwaniami. Składają się na nie między innymi: zdolność podejmowania decyzji i rozwiązywania problemów, krytyczne i kreatywne myślenie, skuteczne komunikowanie się oraz radzenie sobie ze stresem i emocjami. Niewykształcenie umiejętności życiowych u dzieci i młodzieży szkolnej może prowadzić do trudności jednostki w samodzielnym rozwiązywaniu problemów, co przekłada się na wzrost liczby podejmowanych prób samobójczych [17, 20].

\section{Cechy osobowości}

Ryzyko popełnienia zamachu samobójczego jest znacznie większe u osób, które przejawiają określone cechy osobowościowe i charakterologiczne. Zaliczają się do nich między innymi: labilność emocjonalna czy nadmierna autoanaliza. Podkreślanie przez młodzież skrajnych opinii i sądów może przyczynić się do odrzucenia i poczucia bycia niezrozumiałym. Z wysokim ryzykiem samobójczym związana jest również nadmierna wrogość i agresja oraz impulsywność zachowania, a także drażliwość $[13,21]$.

\section{Czynniki ryzyka samobójstw stanowią również choroby psychiczne i uzależnienia:}

\section{Choroby i zaburzenia psychiczne}

U ponad $90 \%$ nieletnich ofiar samobójstw stwierdzono chociaż jedno schorzenie psychiczne, najczęściej z grupy zaburzeń afektywnych, psychotycznych, osobowościowych i lękowych [22]. Zgodnie ze stanowiskiem Światowej Organizacji Zdrowia depresja jest najczęstszym zaburzeniem psychicznym, które stwierdza się przy okolicznościach zamachu samobójczego [16]. Plany samobójcze dzieci dotkniętych depresją rzadziej prowadzą do śmierci niż w grupie młodzieży. W starszej grupie wiekowej częściej dochodzi do negatywnej oceny siebie, otaczającego świata czy przyszłości. Wśród adolescentów ryzyko podjęcia zamachu samobójczego jest wysokie, w szczególności u dziewcząt [23, 24]. 
Zaburzenia odżywiania stanowią duży problem zarówno medyczny, jak i społeczny [25]. Zamachy samobójcze u osób dotkniętych anoreksją nie należą do rzadkości. Około 17\% osób zmagających się z tą chorobą próbowało popełnić samobójstwo [26]. W zaburzeniach odżywiania o charakterze „objadania się", takich jak bulimia, próby samobójcze stanowiły odsetek 27\% [27].

Analiza literatury wskazuje, że na zwiększenie ryzyka zamachu samobójczego u młodzieży z objawami ze spektrum zaburzeń afektywnych składa się: nasilenie epizodu chorobowego (w szczególności depresji), występowanie nastroju mieszanego, obciążony wywiad rodzinny (w kierunku zaburzeń afektywnych oraz podejmowanych prób samobójczych), a także impulsywność, zachowania autoagresywne oraz nadużywanie substancji psychoaktywnych. Wczesna profilaktyka i prawidłowa identyfikacja czynników ryzyka u dzieci i młodzieży z ryzykiem choroby aktywnej dwubiegunowej może znacząco wpłynąć na trafną diagnostykę i interwencje terapeutyczne [28].

\section{Uzależnienia}

Powszechnym zjawiskiem życia społecznego staje się problematyka uzależnień. Alkohol jest najczęściej używaną przez młodzież substancją psychoaktywną. W Polsce, jak i w innych krajach europejskich, odnotowuje się zmiany w zakresie spożywania alkoholu [29]. Obniża się wiek inicjacji alkoholowej, zwiększa się ilość spożywanego alkoholu przez dziewczęta, przyjmowane trunki są mocniejsze i często łączone z substancjami psychoaktywnymi. Państwowa Agencja Rozwiązywania Problemów Alkoholowych zalicza samobójstwa jako negatywne konsekwencje spożywania alkoholu przez młodocianych [30]. Ryzyko popełnienia samobójstwa przez młodocianych spożywających alkohol jest 3-9 razy większe niż u innych [31].

Specyfika używania substancji psychoaktywnych, w szczególności narkotyków, wykazuje w ostatnich latach dużą dynamikę. Różnorodność środków, jak i metod ich przyjmowania może działać zachęcająco na osobę zażywającą [32]. Najczęstszymi substancjami przyjmowanymi przez polską młodzież są: marihuana, leki uspokajające i nasenne, dopalacze, a także różne substancje wziewne [29].

Wspólnym mianownikiem dla nadużywania substancji psychoaktywnych są konsekwencje zdrowotne i rozwojowe, do których należą: utrudnione funkcjonowanie w rolach społecznych, konflikty z prawem, okresowa izolacja i wykluczenie społeczne, zakłócenie rozwoju osobistego, co sprzyja powstawaniu problemów psychicznych, które prowadzą do zaburzeń nastroju, depresji, a także myśli i prób samobójczych [29].

\section{Sposoby zapobiegania i profilaktyka samobójstw}

Zapobieganie samobójstwom powinno obejmować szeroką profilaktykę zaburzeń i zachowań ryzykownych. Skuteczność działań jest zależna od wielu czynników, lecz w największej mierze od zakresu odbiorców, których to wsparcie obejmuje [13]. Profilaktyka samobójstw obejmuje pięć poziomów działań zapobiegawczych:

Poziom I - najogólniejszy - działania obejmują całe społeczeństwo. Mają na celu umacnianie postaw akceptujących życie oraz nabywanie postaw antysuicydalnych, a także rozwój umiejętności rozwiązywania problemów.

Poziom II - dotyczą oddziaływania w populacji, która potencjalnie może być zagrożona wystąpieniem postaw presuicydalnych. Grupa zostaje wyselekcjonowana na podstawie społecznego diagnozowania.

Poziom III - oddziaływanie na określoną jednostkę instytucjonalnie i pozainstytucjonalnie.

Poziom IV - oddziaływanie w sytuacji suicydalnej, która służy przywróceniu jednostce, która dokonała zamachu samobójczego, motywacji do dalszego życia.

Poziom V - oddziaływanie postsuicydalne obejmujące osobę, która próbowała popełnić samobójstwo oraz jej rodzinę [33].

Czynniki, które chronią przed podjęciem zamachu samobójczego można podzielić na: 1) Czynniki rodzinne oraz ważne wydarzenia życiowe; 2) Czynniki poznawcze i osobowościowe (umiejętności społeczne, wiara w siebie, korzystanie z pomocy w sytuacjach trudnych, otwartość na nowe doświadczenia); 3) Czynniki społeczno-kulturowe (zaangażowanie w życie społeczne, uczestnictwo w życiu religijnym, dobre kontakty z rówieśnikami, nauczycielami); 4) Czynniki związane ze zdrowiem psychicznym (wysoki poziom psychicznej odporności, dobre radzenie sobie ze stresem) [34].

Skuteczność działań zależy od etapu, na jakim zostało wykryte zagrożenie. Profilaktyka presuicydalna i oddziaływania postsuicydalne powinny być prowadzone na wielu płaszczyznach i obejmować rolę rodziny, szkoły, systemu ochrony zdrowia, służb mundurowych, a także administracji rządowej i samorządowej [35].

W prewencji samobójstw u dzieci i młodzieży znaczącą rolę odgrywa szkoła, która w dużej mierze jest miejscem kształtującym jednostkę. W niej profilaktyka zachowań suicydalnych powinna obejmować trzy poziomy: 1) Promocję zdrowia i profilaktykę uniwersalną - obejmuje wszystkich uczniów, rodziców oraz nauczycieli. Zakłada szkolenia pracowników szkoły w zakresie potrzeb rozwojowych dzieci, kreowanie wspierającego środowiska w szkole, podnoszenie samooceny uczniów, a także wskazanie im osób, do których mogą się zwrócić po poradę i pomoc. Profilaktyka podstawo- 
wa nie koncentruje się na samobójstwach. Kreowanie pozytywnego klimatu i uczenie umiejętności psychologicznych zapobiega różnym zachowaniom ryzykownym. 2) Profilaktykę selektywną - adresowana jest do grup zwiększonego ryzyka (uczniowie z problemami zdrowotnymi, ekonomicznymi, rodzinnymi, trudnościami w nauce, źle adaptujący się). Koncentruje się na zbieraniu informacji o potrzebach i trudnościach uczniów, pomocy w nauce, udzielaniu wsparcia i motywacji. 3) Profilaktykę wskazującą - dla uczniów z grup wysokiego ryzyka (po zamachu samobójczym, zażywających substancje psychoaktywne). Zakłada stałą obserwację przez przeszkolonych pracowników, udzielanie wsparcia przez nauczycieli, opiekę szkolnego specjalisty, kierowanie ucznia do specjalistów w lokalnym środowisku [36].

Rodzina jako środowisko, w którym od najmłodszych lat kreują się istotne umiejętności, ma kluczowe znaczenie dla prawidłowego rozwoju i w zapobieganiu nieadekwatnym postawom. Zachowania ryzykowne, których przejawy widać w okresie dojrzewania, mają swój początek już w bardzo młodym wieku. Reakcja na wczesnym etapie rozwoju dziecka daje duże szanse na zahamowanie trudności. Rodzice nie powinni być obojętni na zmianę zachowań dziecka, lecz poświęcać mu dużą ilość czasu na rozmowy i wspólne rozwiązywanie problemów. W celu wykrycia jednostki pragnącej targnąc się na swoje życie rola rodziców może być znacząca, ponieważ, będąc świadomymi obserwatorami, mogą oni w odpowiednim czasie udać się po pomoc specjalisty [35, 37].

Pomoc postsuicydalna, czyli ta nakierowana na zapobieganie nawrotom prób samobójczych u jednostek w przeszłości je podejmujących, powinna być skupiona na osobie, która próbowała odebrać sobie życie, a także na jej rodzinie. Światowa Organizacja Zdrowia corocznie wydaje poradnik, który opisuje kwestie rozpowszechniania informacji dotyczących samobójstw, w celu zmniejszenia liczby popełnionych zamachów określanych mianem „efektu Wertera”. Zjawisko to definiowane jest jako wzrost odsetka samobójstw dokonywanych przez młodych ludzi wskutek nagłośnienia przypadków innych samobójstw. Do form pomocy postsuicydalnej należy także tworzenie samopomocowych grup wsparcia, które mogą być przydatne w powrocie do codziennego życia. System opieki postsuicydalnej obejmuje działania lekarzy, psychologów, pracowników socjalnych, duchownych, a także wielu innych służb. Pomoc postsuicydalna powinna gwarantować łatwy dostęp to terapii oraz wsparcia psychologicznego $[13,35,36]$.

\section{Podsumowanie}

Na problem samobójstw u dzieci i młodzieży należy patrzeć wielowymiarowo, łącząc wiedzę z różnych dzie- dzin. Konieczne jest jej nieustanne poszerzanie, aby lepiej zrozumieć jakie czynniki prowadzą do podejmowania decyzji o zakończeniu życia przez młodocianych. Zwiększenie świadomości społeczeństwa dotyczące uwarunkowań samobójstw może wpłynąć na zmniejszenie ilości zamachów poprzez wczesną identyfikację problemów jednostki przez najbliższe otoczenie. Profilaktyka zachowań ryzykownych, w tym samobójstw, powinna być zadaniem priorytetowym dla wielu placówek, organizacji i służb.

\section{Piśmiennictwo}

1. Kosiba B, Przybyszewska W, Sołtyszewski I. Wybrane aspekty zachowań samobójczych. JoMS. 2017; 1(11): 83-111.

2. Czabański A, Mariański J. Problematyka samobójstw w ujęciu Marii Jarosz. TiM. 2018; 2(24): 225-241.

3. Durkheim E. Samobójstwo. Sułek A. [wyd.] Logika analizy socjologicznej, wybór tekstów. Warszawa 1979.

4. Kuberska-Przekwas K. Samobójstwa dzieci i młodzieży jako choroba społeczna. Warmińsko-Mazurski Kwartalnik Naukowy. Nauki Społeczne. Wyższa Szkoła Informatyki i Ekonomii Towarzystwa Wiedzy Powszechnej. 2014; 9: 51-69.

5. Korzeniowski L, Pużyński S. [red.] Encyklopedyczny słownik psychiatrii. Państwowy Zakład Wydawnictw Lekarskich. Warszawa 1961.

6. Makara-Studzińska M. Wybrane zagadnienia z problematyki suicydologii. Annales Universitatis Mariae Curie-Skłodowka. 2001; 17(26): 219-230.

7. Płużek Z. Psychologiczny aspekt samobójstw. Wydawnictwo „Znak”. Kraków 1972.

8. Raniszewska-Wyrwa A. Problem samobójstw w perspektywie psychiatrycznej i psychologicznej. Acta Universitatis Lodziensis. Folia Psychologica. 2010; 14: 45-62.

9. Polska Policja. Zamachy samobójcze od 2017 roku. Statystyka.

10. Rigel E. Gdy życie traci sens. Rozważania o samobójstwie. Wydawnictwo Glob. Szczecin 1987.

11. Dzierżanowski J. Psychospołeczna sytuacja dziecka w małżeństwach rozwodzących się. W: D. Krok, P. Landwójtowicz [red.]. Rodzina w nurcie społecznych przemian. Opole 2010.

12. Gawda K. Rodzina z jednym rodzicem jako środowisko wychowawcze. Teol. Człow. 2018; 3(43): 141-152.

13. Rzadkowska M. Zachowania samobójcze wśród dzieci i młodzieży - charakterystyka ryzyka i profilaktyka. Studia Prawnicze. Rozprawy i Materiały. 2016; 1(18): 161-179.

14. Makara-Studzińska M. Przyczyny prób samobójczych u młodzieży w wieku 14-18 lat. Psychiatria. 2013; 2(10): 76-83.

15. Greenberg T, Velting D, Shaffer D. Youth suicide risk and preventions: A review of the past 10 years. J Am Acad Child Adolesc Psychiatry. 2003; 42(4): 386-405.

16. Dąbkowska M. Traumatyczne doświadczenia w dzieciństwie jako czynniki ryzyka zaburzeń psychicznych wieku rozwojowego i dorosłości. Psychiatr. Psychol. Klin. 2006; 6(4): 203-210.

17. Kielan A, Olejniczak D. Czynniki ryzyka oraz konsekwencje zachowań samobójczych z uwzględnieniem problematyki samobójstw dzieci i młodzieży. Dziecko Krzywdzone. Teoria, badania, praktyka. 2018; 17(3): 9-26.

18. Włodarczyk J. Wykorzystywanie seksualne w dzieciństwie a konsekwencje w życiu dorosłym. Raport z badań. Fundacja Dajemy Dzieciom Siłę. Warszawa 2016. 
19. Beisert M, Izdebska A. Wykorzystanie seksualne dzieci. Dziecko krzywdzone. 2012; 2(39): 48-66.

20. World Health Organization. Division of Mental Health. Life skills education for children and adolescents in schools. Genewa 1997.

21. Penkowska M. Dziecko po próbie samobójczej wstępna analiza badań przeprowadzonych w Klinice Psychiatrii Rozwojowej, Zaburzeń Psychotycznych i Wieku Podeszłego Wojewódzkiego Szpitala Psychiatrycznego im. Prof. T. Bilikiewicza GUM. Zdrowie i Dobrostan. 2014; 3: 109-116.

22. Namysłowska I. [red.] Psychiatria dzieci i młodzieży. Wydawnictwo Lekarskie PZWL. Warszawa 2011.

23. Kalinowska S, Nitsch K, Duda P, Trześniowska-Drukała B, Samochowiec J. Depresja u dzieci i młodzieży - obraz kliniczny, etiologia, terapia. Roczniki Pomorskiej Akademii Medycznej w Szczecinie. 2013; 59(1): 32-36.

24. Kołodziejek M. Depresja u dzieci i młodzieży: podstawy teoretyczne, psychoterapia poznawczo-behawioralna. Psychoterapia. 2008; 145(2): 15-33.

25. Bator E, Bronkowska M, Ślepecki D, Biernat J. Anoreksja przyczyny, przebieg, leczenie. Now Lek. 2011; 80(3): 184-191.

26. Bulik CM, Thornton L, Poyastro Pinheiro A, Plotnicov K, Klump KL, Brandt $\mathrm{H}$ et al. Suicide Attempts in Anorexia Nervosa. Psychosom Med. 2008; 70: 378-383.

27. Forcano L, Fernandez-Aranda F, Alvarez-Moya E, Bulik C, Granero R, Gratacos M et al. Suicide attempts in bulimia nervosa: Personality and psychopathological correlates. European Psychiatry. 2009; 24: 91-97.

28. Rajewska-Rager A, Lepczyńska N, Sibilski P. Czynniki ryzyka samobójstw u dzieci i młodzieży ze spektrum choroby i chorobą afektywną dwubiegunową o wczesnym początku. Psychiatr. Pol. 2015; 49(3): 477-488.

29. Ostaszewski K. Używanie substancji psychoaktywnych jako przejaw zachowań ryzykownych młodzieży szkolnej. Dziecko Krzywdzone. Teoria, badania, praktyka. 2017; 16(1): 132-145.

30. Banach M, Kowalewski I. Alkoholizm wśród młodzieży. Kompendium wiedzy dla pedagogów i pracowników socjalnych. Wydanie I. Wydawnictwo Scriptum. Kraków 2014.
31. Kusiak K, Szewczyk L, Włoszczak-Szubzda A. Czynniki biopsychospołeczne a częstość występowania alkoholu wśród młodzieży. Studia i Prace Pedagogiczne. 2017; 4: 99-135.

32. Motyka M. Dynamika zjawiska narkomanii: nowe populacje zażywających narkotyki. Probl. Hig. Epidemiol. 2013; 94(3): 435-445.

33. Hołyst B. Suicydologia. LexisNexis. Warszawa 2012.

34. Brodniak W. Ramowy Program zapobiegania samobójstwom w Polsce na lata 2012-2015. Instytut Psychiatrii i Neurologii. Warszawa 2012.

35. Bąbik A, Olejniczak D. Uwarunkowania i profilaktyka samobójstw wśród dzieci i młodzieży w Polsce. Dziecko Krzywdzone. Teoria, badania, praktyka. 2014; 13(2): 2014.

36. Szymańska J. Zapobieganie samobójstwom wśród dzieci i młodzieży. Poradnik dla pracowników szkół i placówek oświatowych oraz rodziców. Wydanie III. Warszawa 2012.

37. Malicka-Gorzelańczyk H. Opinie młodzieży o samobójstwie. Wydawnictwo Akademii Bydgoskiej im. Kazimierza Wielkiego. Bydgoszcz 2002.

Artykuł przyjęty do redakcji: 18.11.2019.

Artykuł przyjęty do publikacji: 01.04.2020.

Źródło finansowania: Praca nie jest finansowana z żadnego źródła. Konflikt interesów: Autorzy deklarują brak konfliktu interesów.

Adres do korespondencji:

Kinga Kołodziej

ul. Michałowskiego 12

31-126 Kraków

tel.: 126324881

e-mail: kingakolodziej1@gmail.com

Wydział Nauk o Zdrowiu, Uniwersytet Jagielloński Collegium Medicum 